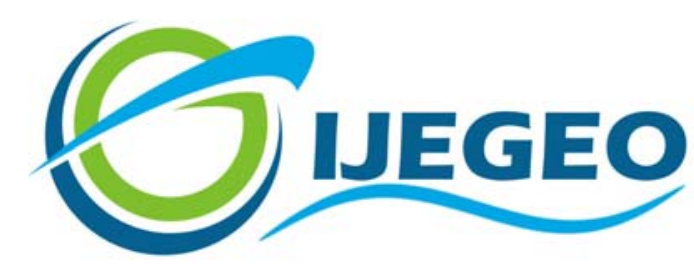

International Journal of Environment and Geoinformatics (IJEGEO) is an international, multidisciplinary, peer reviewed, open access journal.

\title{
Experimental and Theoretical Aspects of Azo Dye Degradation by UV/H2O2 Process: Review and experimental comparison of some kinetic rate expressions
}

\section{Başak SAVUN-HEKİMOĞLU}

\author{
Chief in Editor \\ Prof. Dr. Cem Gazioğlu \\ Co-Editors \\ Prof. Dr. Dursun Zafer Şeker, Prof. Dr. Şinasi Kaya, \\ Prof. Dr. Ayşegül Tanık and Assist. Prof. Dr. Volkan Demir
}

Editorial Committee (December 2020)

\begin{abstract}
Assos. Prof. Dr. Abdullah Aksu (TR), Assit. Prof. Dr. Uğur Algancı (TR), Prof. Dr. Bedri Alpar (TR), Prof. Dr. Levent Bat (TR), Prof. Dr. Paul Bates (UK), İrşad Bayırhan (TR), Prof. Dr. Bülent Bayram (TR), Prof. Dr. Luis M. Botana (ES), Prof. Dr. Nuray Çağlar (TR), Prof. Dr. Sukanta Dash (IN), Dr. Soofia T. Elias (UK), Prof. Dr. A. Evren Erginal (TR), Assoc. Prof. Dr. Cüneyt Erenoğlu (TR), Dr. Dieter Fritsch (DE), Prof. Dr. Çiğdem Göksel (TR), Prof.Dr. Lena Halounova (CZ), Prof. Dr. Manik Kalubarme (IN), Dr. Hakan Kaya (TR), Assist. Prof. Dr. Serkan Kükrer (TR), Assoc. Prof. Dr. Maged Marghany (MY), Prof. Dr. Michael Meadows (ZA), Prof. Dr. Nebiye Musaoğlu (TR), Prof. Dr. Masafumi Nakagawa (JP), Prof. Dr. Hasan Özdemir (TR), Prof. Dr. Chryssy Potsiou (GR), Prof. Dr. Erol Sarı (TR), Prof. Dr. Maria Paradiso (IT), Prof. Dr. Petros Patias (GR), Prof. Dr. Elif Sertel (TR), Prof. Dr. Nüket Sivri (TR), Prof. Dr. Füsun Balık Şanlı (TR), Prof. Dr. Uğur Şanlı (TR), Duygu Ülker (TR), Prof. Dr. Seyfettin Taş (TR), Assoc. Prof. Dr. Ömer Suat Taşkın (US), Assist. Prof. Dr. Tuba Ünsal (US), Dr. İnese Varna (LV), Dr. Petra Visser (NL), Prof. Dr. Selma Ünlü (TR), Prof. Dr. Murat Yakar (TR), Assit. Prof. Dr. Sibel Zeki (TR)
\end{abstract}

Abstracting and Indexing: TR DIZIN, DOAJ, Index Copernicus, OAJI, Scientific Indexing Services, International Scientific Indexing, Journal Factor, Google Scholar, Ulrich's Periodicals Directory, WorldCat, DRJI, ResearchBib, SOBIAD 


\title{
Review Article
}

\section{Experimental and Theoretical Aspects of Azo Dye Degradation by $\mathrm{UV} / \mathrm{H}_{2} \mathrm{O}_{2}$ Process: Review and experimental comparison of some kinetic rate expressions}

\author{
Başak Savun-Hekimoğlu \\ Istanbul University, Institute of Marine Sciences and Management, 34134 VEFA Fatih-İstanbul/TR
}

Received 27 Aug 2020

Accepted 16 Sep 2020

E-mail: basak.savun@istanbul.edu.tr

How to cite: Savun-Hekimoğlu, B. (2020). Experimental and Theoretical Aspects of Azo Dye Degradation by UV/H2O2 Process: Review and
experimental comparison of some kinetic rate expressions. International Journal of Environment and Geoinformatics (IJEGEO), 7(3): 289-299, DOI: 10.30897/ijegeo.786158

\begin{abstract}
Due to their unique properties, azo dyes are extensively used, especially in the textile industry. Due to their low biodegradability, these compounds cannot be treated in wastewater treatment plants and discharges of these effluents poses a serious threat to the receiving water bodies. In the literature, several advanced oxidation processes have been studied for decolorization and mineralization of these toxic compounds. Among these advanced oxidation processes, the $\mathrm{UV} / \mathrm{H}_{2} \mathrm{O}_{2}$ process has attracted great attention with its high efficiency in removing these compounds. The goal of this paper is to review the kinetic rate expressions developed to describe azo dye degradation by $\mathrm{UV} / \mathrm{H}_{2} \mathrm{O}_{2}$ process. A detailed review of pseudo-first-order reaction mechanism, as well as reactor design models, is provided. Finally, a set of experiments are conducted with Reactive Black 5 to compare the model estimations with the observed data. In addition, a regression model is developed using response surface methodology to optimize operating conditions. The experimental results indicate that the optimum $\mathrm{pH}$ value that gives the maximum reaction constant is 5.74 . Moreover, initial dye concentration is found to be a more significant parameter for decay rate constant than $\mathrm{pH}$ value. The open questions and future research topics are also discussed.
\end{abstract}

Keywords: Azo dye, Photolysis, $\bullet \mathrm{OH}$, Response surface methodology, $\mathrm{UV} / \mathrm{H}_{2} \mathrm{O}_{2}$

\section{Introduction}

Azo dyes are the largest group of synthetic dyes, accounting for more than $70 \%$ percent of all the commercial dyes produced worldwide (Chung, 2016). In 1991, the Food and Drug Administration has certified more than 3000 tons of azo dyes for use in foods, pharmaceuticals and personal care products. There are currently over 2000 azo dyes and more than $7 \times 10^{5}$ tons of these dyes are manufactured globally and extensively used in the textile industries (Iark et al., 2019). A certain amount of them is inevitably lost in the process of their manufacturing and left in environmentally hazardous industrial wastes. The main source of dye water pollution in water is the unfixed excess dyes that are discharged with the significant volumes of water as textile effluents (Körbahti, 2007; Hassaan and Nemr, 2017).

The chemical structures of the azo dyes are distinguished by highly substituted aromatic rings joined by one or more azo groups which makes them recalcitrant to the conventional wastewater treatment processes (Song et al., 2010). Hence, they are discharged with the wastewater treatment plant effluents and end up in the receiving water bodies. Once these compounds are released into the water sources they disturb aquatic life by reducing the reoxygenation capacity of water and blocking sunlight. Azo dyes also have a significant environmental effect due to their degradation products, including those known to be highly carcinogenic aromatic amines (Chiu et al., 2019). Recent studies show that these dyes have harmful impacts on the environment as well as on human health (Hassaan and Nemr, 2017). The removal of azo dyes from textile wastewater before discharge is thus a serious environmental concern. Common approaches such as chemical coagulation, air flotation, and adsorption can be used to remove the dyes from wastewater (Chafi et al., 2011; Lu et al., 2010). Such conventional approaches, however, primarily transfer the pollutants from one phase to another, without reducing their toxicity. Advanced oxidation processes on the other hand are alternative methods to completely remove and mineralize these recalcitrant pollutants (Cuerda-Correa et al., 2019).

Advanced Oxidation Processes (AOPs), which involves the generation of highly oxidative species, especially the hydroxyl radical $(\bullet \mathrm{OH})$ for the oxidation of a broad range of recalcitrant contaminants, has drawn the attention of environmental engineers in recent years (Muniyasamy et al., 2020). The most common AOPs for azo dye degradation are ozonation, $\mathrm{UV} / \mathrm{H}_{2} \mathrm{O}_{2}$, sonication, Fenton processes and their combinations (Viswanathan, 2018). Among various combined processes the $\mathrm{UV} / \mathrm{H}_{2} \mathrm{O}_{2}$ process has several advantages such as low capital cost and no solid waste generation (El-Dein et al., 2001). In this process, photolysis of the added $\mathrm{H}_{2} \mathrm{O}_{2}$ results in the formation of $\cdot \mathrm{OH}$ which is recognized with nonselectivity and strong oxidizing capacity stronger than all conventional oxidizing agents. 
Many authors have investigated the kinetics of degradation of azo dyes by $\mathrm{UV} / \mathrm{H}_{2} \mathrm{O}_{2}$ and developed models for the interpretation of kinetic results (Muruganandham and Swaminathan, 2004; Gultekin and Ince, 2004; Shu et al., 2009; Aleboyeh et al., 2003; Galindo and Kalt, 1999; El-Dein et al., 2001; Behnajady et al., 2004; Behnajady et al., 2006; Malik and Sanyal, 2004).

Response surface methodology (RSM) is considered as the most effective for modeling, analysis and optimization of multivariable systems. A response surface model provides an approximation for the system response (e.g., percent yield of a reaction) for given values of each variable that are included in the study and has the potential to influence the response (e.g., temperature and pressure). Although a response surface model can include higher-order terms of independent variables, a full second-order polynomial empirical model is widely used to describe multifactor chemical processes (Hartley 1959; Deming 1988).

This paper aims to review the kinetic rate expressions developed for homogeneous photocatalytic azo dye degradation by the $\mathrm{UV} / \mathrm{H}_{2} \mathrm{O}_{2}$ process. The kinetic rate expressions reviewed in the first section of the paper are given in Table 1. Furthermore, some of the expressions are tested using experimental data achieved through laboratory experiments and a Response Surface Model (RSM) design is used to determine the optimum $\mathrm{pH}$ that maximizes mineralization and decolorization. In addition, sensitivity analysis is performed using a linear regression model with Standardized Regression Coefficients (SRC). It is important to note that, reaction rate constant expressions of the reviewed studies are not linked to each other. In other words, the rate constant might be expressed with the same term (such as $\mathrm{k}_{1}$ and $\mathrm{k}_{2}$ ) but does not necessarily have the same meaning in the different studies reviewed.

Table 1. Some kinetic rate expressions for oxidation of azo dyes with $U V / \mathrm{H}_{2} \mathrm{O}_{2}$.

\begin{tabular}{|c|c|}
\hline Reference & Expression \\
\hline Colonna et al. & $2 . \emptyset . k_{1} \cdot I_{a} \cdot\left[C_{d y e}\right]$ \\
\hline$(1999)$ & $-\frac{d t}{d t}=\overline{\left(k_{1}-k_{2}\right) \cdot\left[C_{d y e}\right]+k_{2} \cdot\left[C_{d y e}\right]_{0}}$ \\
\hline Behnajady et al. (2004) & $-\frac{d\left[C_{d y e}\right]}{d t}=\frac{2 \cdot \emptyset \cdot k_{1} \cdot I_{0} \cdot F_{H 2 O 2}}{k_{2} \cdot\left[C_{d y e}\right]_{0}} \cdot\left[C_{d y e}\right]$ \\
\hline & $F_{\mathrm{H} 2 \mathrm{O} 2}=\varepsilon_{\mathrm{H} 2 \mathrm{O} 2} \cdot\left[\mathrm{H}_{2} \mathrm{O}_{2}\right] /\left(\varepsilon_{\mathrm{H} 2 \mathrm{O} 2} \cdot\left[\mathrm{H}_{2} \mathrm{O}_{2}\right]+\varepsilon_{\text {dye }} \cdot\left[C_{d y e}\right]\right)$ \\
\hline Malik and Sanyal, (2004) & $\mathrm{k}_{\mathrm{obs}}=8.11\left[\mathrm{H}_{2} \mathrm{O}_{2}\right]_{0}^{0.63}$ \\
\hline El-Dein et al. (2001) & $-\frac{d C_{d y e}}{d t}=\frac{k_{1 o} C_{H 2 O 2}}{k_{2}+C_{H 2 O 2}} C_{d y e} I_{o}$ \\
\hline Behnajady et al. (2006) & $\begin{array}{c}-\frac{d C_{d y e}}{d t}=\left(2 \cdot 10^{-4} \cdot \mathrm{I}_{0}^{0.75}+3 \cdot 10^{-4} \cdot \mathrm{I}_{0}^{1.38} \cdot\left[\mathrm{H}_{2} \mathrm{O}_{2}\right]_{0}^{0.49}\right) \cdot \psi \text { dye. }[\text { Cdye }] \\
-\frac{d C_{d y e}}{d t}=\left(2 \cdot 10^{-4} \cdot \mathrm{I}_{0}^{0.75}+0.1 \cdot \mathrm{I}_{0}^{1.38} \cdot\left[\mathrm{H}_{2} \mathrm{O}_{2}\right]_{0}^{-0.39}\right) \cdot \psi \text { dye. }[\text { Cdye }]\end{array}$ \\
\hline Shen and Wang (2002) & $\int_{C d y e, \text { in }}^{\text {Cdy }} \frac{d C d y e}{C_{d y e}^{p} \cdot e^{-\varepsilon d y e . C d y e \cdot m(r-r i)}}=k\left[I_{0} \cdot \frac{r i}{r} e^{-(E+\varepsilon H 2 O 2 . C H 2 O 2) \cdot(r-r i)}\right]^{\mathrm{m}} \cdot\left[\mathrm{H}_{2} \mathrm{O}_{2}\right]^{\mathrm{n}} \cdot \mathrm{L} / \mathrm{v}_{\mathrm{z}}$ \\
\hline Chang et al. (2010) & $-r_{\text {dye } 0}=\frac{k_{01} k_{a} I_{0} \exp \left(-k_{H}[H 2 O 2]-k_{D}[\text { Dye }]\right)[H 2 O 2][D y e]\left(1+k_{b}[H 2 O 2]\right.}{[H 2 O 2]+k_{a}[\text { Dye }]+k_{a} k_{b}[\text { Dye }][H 2 O 2]}$ \\
\hline
\end{tabular}

Current status of kinetic rate expressions for photocatalytic dye oxidation

\section{Pseudo-First-Order Models}

Several studies revealed that the azo dye degradation by $\mathrm{UV} / \mathrm{H}_{2} \mathrm{O}_{2}$ can be approximated with a first-order decay (Muruganandham and Swaminathan, 2004; Gultekin and Ince, 2004; Shu et al., 2009; Neamtu et al., 2002; Aleboyeh et al., 2003). Taking into account the effect of hydroxyl radical concentration the main kinetic pathway of azo dyes removal is expressed as follows:

$-\frac{d C_{d y e}}{d t}=k_{2} \cdot C_{d y e} \cdot C_{O H} \cdot$

where the concentration of azo dye is expressed in $\mathrm{C}_{\mathrm{dye}}$ and the concentration of $\mathrm{OH} \bullet$ is denoted by $\mathrm{C}_{\mathrm{OH}}$. (mol/L).

The $\mathrm{C}_{\mathrm{OH}}$. can be considered to be a constant in the presence of excess hydrogen peroxide by pseudostationary hypothesis (Neamtu et al., 2002). Equation 1, therefore, is simplified into a kinetic model of the pseudo-first-order given in Equation 2: $-\frac{d C_{d y e}}{d t}=k_{1} \cdot C_{d y e}$

In Equation 2, $\mathrm{k}_{1}$ is the pseudo-first-order rate constant. Pseudo steady-state approximation, in which the concentration of hydroxyl radicals $(\mathrm{OH} \bullet)$ does not change with the reaction time, is commonly used (Kumoro et al., 2017; Rajchel-Mieldzioć et al., 2020; Fard et al., 2016; El-Dein et al., 2003). This approach has been widely used to eliminate the nonmeasurable radicals concentration, correlating it as a function of $\mathrm{H}_{2} \mathrm{O}_{2}$ concentration (Neamtu et al, 2002; El-Dein et al., 2003).

Colonna et al. (1999) proposed a kinetic model taking into account that decolorization is complete in a relatively shorter amount of time compared to the duration that mineralization requires. According to that hypothesis, fluorescent intermediates are generated initially. Further reactions with hydroxyl radicals and photochemical processes then lead to smaller organic molecules, that will eventually be completely mineralized. The reactions are shown in Eq 3- 6: 
$\mathrm{H}_{2} \mathrm{O}_{2}+\mathrm{hv} \rightarrow 2 \mathrm{HO} \bullet$

Dye+ $\mathrm{HO} \bullet \rightarrow$ Int $\quad\left(\mathrm{k}_{1}\right)$

Int $+\mathrm{HO} \bullet \rightarrow \mathrm{P}_{1} \quad\left(\mathrm{k}_{2}\right)$

$\mathrm{P}_{1}+\mathrm{hv} \rightarrow \mathrm{P}_{2} \quad\left(\mathrm{k}_{3}\right)$

In the study of Colonna et al. (1999), these chain reactions are expressed by a simplified model of which kinetic equations are given as follows:

$-\frac{d\left[\mathrm{H}_{2} \mathrm{O}_{2}\right]}{d t}=2 . \varnothing . I_{a}$

$-\frac{d\left[C_{d y e}\right]}{d t}=k_{1} \cdot\left[C_{d y e}\right] \cdot\left[C_{O H} \cdot\right]$

$-\frac{d[O H \bullet]}{d t}=k_{1} \cdot\left[C_{d y e}\right] \cdot\left[C_{O H} \cdot\right]+k_{2} \cdot[$ Int $] .\left[C_{O H} \cdot\right]-2 . \emptyset \cdot I_{a}$

$-\frac{d[\text { Int }]}{d t}=k_{2} \cdot[$ Int $] \cdot\left[C_{\mathrm{OH}}\right]-k_{1} \cdot\left[C_{d y e}\right] \cdot\left[C_{\mathrm{OH}}\right]$

$-\frac{d\left[P_{1}\right]}{d t}=k_{2} \cdot[$ Int $] .\left[C_{O H} \cdot\right]+k_{3} \cdot\left[P_{1}\right]$

$\frac{d\left[P_{2}\right]}{d t}=k_{3} \cdot\left[P_{1}\right]$

where $\varnothing$ is the quantum yield of the photochemical hydrogen peroxide dissociation, $\mathrm{I}_{\mathrm{a}}$ is the $\mathrm{H}_{2} \mathrm{O}_{2}$-absorbed radiation intensity.

In that study $\mathrm{k}_{2}$ is the second-order kinetic constant for the hydroxyl radical attack to intermediate products. Equation 13 can be derived from the aforementioned kinetic equations by applying steady-state approximation to [OH•] (Colonna et al., 1999).

$-\frac{d\left[C_{d y e}\right]}{d t}=\frac{2 \cdot \emptyset \cdot k_{1} \cdot I_{a} \cdot\left[C_{d y e}\right]}{\left(k_{1}-k_{2}\right) \cdot\left[C_{d y e}\right]+k_{2} \cdot\left[C_{d y e}\right]_{0}}$

where $\left[\mathrm{C}_{\text {dye }}\right]_{0}$ is the initial dye concentration and $[$ Int $]+\left[\mathrm{C}_{\text {dye }}\right] \approx\left[\mathrm{C}_{\text {dye }}\right]_{0}$.

$\mathrm{k}_{2}$ has been reported to be of the order of $10^{9} \mathrm{~L} \mathrm{~mol}^{-1} \mathrm{~s}^{-1}$ (Buxton et al., 1988; Kochany et al., 1992). Therefore neglecting $\left(\mathrm{k}_{1}-\mathrm{k}_{2}\right)$ in the denominator of Equation 13 yields:

$-\frac{d\left[C_{d y e}\right]}{d t}=\frac{2 \cdot \emptyset \cdot k_{1} \cdot I_{a} \cdot\left[C_{d y e}\right]}{k_{2} \cdot\left[C_{d y e}\right]_{0}}=\frac{2 \cdot \emptyset \cdot k_{1} \cdot I_{0} \cdot\left[C_{d y e}\right]}{k_{2} \cdot\left[C_{d y e}\right]_{0}} \cdot F \cdot\left(1-10^{-A}\right)$

where $\mathrm{F}$ is the fraction of light absorbed by $\mathrm{H}_{2} \mathrm{O}_{2}$, A represents the total absorbance of the solution within the same wavelength range, $I_{a}$ is the intensity of the radiation absorbed by the sample and $I_{0}$ is the radiation intensity impinging on the solution.

Due to the high absorption of the dye during the initial part of the process, the following can be taken for consideration under continuous irradiation $\left(1-10^{-\mathrm{A}}\right) \approx 1$ so Equation 14 becomes:

$-\frac{d\left[C_{d y e}\right]}{d t}=\frac{2 . \emptyset \cdot k_{1} \cdot I_{0} \cdot F_{H 2 O 2}}{k_{2} \cdot\left[C_{d y e}\right]_{0}} \cdot\left[C_{d y e}\right]$

In that equation fraction of light absorbed by hydrogen peroxide $\left(\mathrm{F}_{\mathrm{H} 2 \mathrm{O} 2}\right)$ is a parameter. $\mathrm{F}_{\mathrm{H} 2 \mathrm{O} 2}$ was explained in a more detailed manner in the study of Behnajady et al. (2004). In that study, the authors used the same model for azo dye degradation process. The major contribution of their study is a detailed explanation of absorbed radiation intensity by sample $\left(\mathrm{I}_{\mathrm{a}}\right)$ which is given in Equations 16-17:
$\mathrm{I}_{\mathrm{a}}=\mathrm{I}_{0} \cdot F_{\mathrm{H} 2 \mathrm{O} 2} \cdot\left[1-\exp \left(-2 \cdot 3 \mathrm{~L} \cdot\left(\varepsilon_{\mathrm{H} 2 \mathrm{O} 2} \cdot\left[\mathrm{H}_{2} \mathrm{O}_{2}\right]+\varepsilon_{\text {dye }} \cdot\left[C_{d y e}\right]\right)\right]\right.$

$F_{\mathrm{H} 2 \mathrm{O} 2}=\varepsilon_{\mathrm{H} 2 \mathrm{O} 2} \cdot\left[\mathrm{H}_{2} \mathrm{O}_{2}\right] /\left(\varepsilon_{\mathrm{H} 2 \mathrm{O} 2} \cdot\left[\mathrm{H}_{2} \mathrm{O}_{2}\right]+\varepsilon_{\text {dye }} \cdot\left[C_{d y e}\right]\right)$

where $\mathrm{L}$ is the optical path length of the system, $\varepsilon_{\mathrm{H} 2 \mathrm{O} 2}$ and $\varepsilon_{\mathrm{AO} 7}$ are the molar extinction coefficients for $\mathrm{H}_{2} \mathrm{O}_{2}$ and the dye, respectively.

In their expression authors state that the exponential terms given in brackets in Equation 16 are negligible due to high absorbance of the dye and $\mathrm{H}_{2} \mathrm{O}_{2}$ in the initial part of the process. So it can be written as:

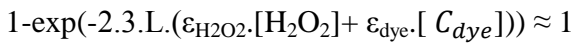

Substituting Equation 18 and 16 into Equation 15 yields Equation 19:

$-\frac{d\left[C_{d y e}\right]}{d t}=k_{a p} \cdot\left[C_{d y e}\right]$

where

$k_{a p}=\frac{2 \cdot \emptyset \cdot k_{1} \cdot I_{0} \cdot F_{H 2 O 2}}{k_{2} \cdot\left[C_{d y e}\right]_{0}}$

Note that in these equations the pseudo-first-order rate constant $\left(\mathrm{k}_{\mathrm{ap}}\right)$ is a function of $\mathrm{H}_{2} \mathrm{O}_{2}$ and dye concentration. On the other hand results of experiments in that study indicate that $\mathrm{k}_{\mathrm{ap}}$ increases with an increasing quantity of $\mathrm{H}_{2} \mathrm{O}_{2}$ and reaches nearly a constant value above optimum concentration. Another study that aims to investigate the dependence of $\mathrm{k}$ on the concentration of $\mathrm{H}_{2} \mathrm{O}_{2}$ and the radiation flux was conducted by El-Dein et al. (2001). In agreement with Behnajady et al. (2004), experimental results showed that at low $\mathrm{H}_{2} \mathrm{O}_{2}$ concentrations, observed $\mathrm{k}$ increased proportionally to the $\mathrm{H}_{2} \mathrm{O}_{2}$ concentration. A maximum rate has been observed at higher concentrations. They described that nonlinear relationship with the following kinetic expression:

$k=\frac{k_{1} C_{\mathrm{H} 2 \mathrm{O} 2}}{k_{2}+C_{\mathrm{H} 2 \mathrm{O} 2}}$

where both $\mathrm{k}_{1}$ and $\mathrm{k}_{2}$ can depend on $\mathrm{I}_{0}$. For the case that $\mathrm{C}_{\mathrm{H} 2 \mathrm{O} 2} \gg>\mathrm{k}_{2}$ Equation 21 becomes $\mathrm{k}=\mathrm{k}_{1}$.

The authors plotted $\mathrm{k}_{1}$ versus UV intensity and observed a linear relationship which can be expressed as:

$\mathrm{k}_{1}=\mathrm{k}_{\mathrm{a}} \cdot \mathrm{I}$

Therefore Equation 22 was written as:

$-\frac{d C_{d y e}}{d t}=\frac{k_{a} C_{\mathrm{H} 2 \mathrm{O} 2}}{k_{2}+C_{\mathrm{H} 2 \mathrm{O} 2}} C_{d y e} I$

In that study, El-Dein et al. (2001) developed a reaction rate expression taking into account the effect of both $\mathrm{H} 2 \mathrm{O} 2$ and UV flux irradiation based on reaction kinetics but neglected the effect of hydrogen peroxide dissociation and initial dye concentration. However, several studies are showing the dependence of the reaction rate to the initial dye concentration (Galindo and Kalt, 1999; Kdasi et al., 2004; Shu et al., 1994). The effect of initial dye concentration will also be tested with the experimental data in the last section of this paper. 
Malik and Sanyal, (2004) carried out a kinetic study considering the contribution of the UV light by itself and the combined UV light and $\mathrm{H}_{2} \mathrm{O}_{2}$ reaction. They considered that during $\mathrm{UV} / \mathrm{H}_{2} \mathrm{O}_{2}$ decolorization of azo dye two reactions take place in parallel; a pure photolysis reaction and an $\mathrm{H}_{2} \mathrm{O}_{2}$-assisted oxidation reaction. Thus, the overall rate of decolorization was expressed as:

$$
-\frac{d C_{d y e}}{d t}=k_{U V} \cdot C_{d y e}^{a} \cdot I^{b}+k_{U V / H 2 O 2} C_{d y e}^{c} \cdot C_{H 2 O 2}^{d} \cdot I^{e}
$$

where $\mathrm{C}_{\text {dye }}$ is the dye concentration $(\mathrm{M}), \mathrm{k}_{\mathrm{UV}}$ is the rate constant of dye removal with UV radiation alone, I is the $\mathrm{UV}$ radiation intensity $\left(\mathrm{kW} / \mathrm{m}^{2}\right), \mathrm{k}_{\mathrm{UV} / \mathrm{H} 2 \mathrm{O} 2}$ is the rate constant of dye removal with UV radiation in the presence of $\mathrm{H}_{2} \mathrm{O}_{2}, \mathrm{C}_{\mathrm{H} 2 \mathrm{O} 2}$ is the concentration of $\mathrm{H}_{2} \mathrm{O}_{2}$ $(\mathrm{M})$, and a-e are reaction orders.

It was hypothesized that $\mathrm{H}_{2} \mathrm{O}_{2}$ acted as a catalyst in the $\mathrm{UV} / \mathrm{H}_{2} \mathrm{O}_{2}$ process because the change in concentration of $\mathrm{H}_{2} \mathrm{O}_{2}$ during dye removal was nearly constant. With that consideration and since the light intensity was kept constant, the rate expression (24) was simplified as:

$-\frac{d c_{d y e}}{d t}=\left(k_{U V}^{\prime}+k_{U V / H 2 O 2}^{\prime}\right) C_{d y e}^{n}$

where $\mathrm{k}^{\prime}{ }_{\mathrm{UV}}=\mathrm{k}_{\mathrm{UV}} \cdot \mathrm{I}^{\mathrm{b}}$ and $\mathrm{k}^{\prime}{ }_{\mathrm{UV} / \mathrm{H} 2 \mathrm{O} 2}=\mathrm{k}_{\mathrm{UV} / \mathrm{H} 2 \mathrm{O} 2} \cdot \mathrm{C}_{\mathrm{H} 2 \mathrm{O} 2}{ }^{\mathrm{d}} \cdot \mathrm{I}^{\mathrm{e}} ; \mathrm{n}$ is the order of reaction.

The results of the experiment in their study indicated that the value of $n$ was 1 . The rate expression can, therefore, be considered to be pseudo-first-order in dye concentration like other studies in the literature. The values of $\mathrm{k}_{\mathrm{obs}}=\left(k_{U V}^{\prime}+k_{U V / \mathrm{H} 2 \mathrm{O} 2}^{\prime}\right)$ and $\mathrm{k}_{\mathrm{UV} / \mathrm{H} 2 \mathrm{O} 2}$ for various $\mathrm{H}_{2} \mathrm{O}_{2}$ concentrations were determined from experimental data using a pseudo-first-order kinetic model. A straight line was given by a logarithmic plot of $\mathrm{k}_{\mathrm{obs}}$ against the initial concentration of $\mathrm{H}_{2} \mathrm{O}_{2}(\mathrm{R}=0.989)$. Thus, the pseudo-first-order rate constant $\left(\mathrm{k}_{\mathrm{obs}}\right)$ as a function of $\mathrm{H}_{2} \mathrm{O}_{2}$ concentration up to the $5.88 \times 10^{-3} \mathrm{M}$ is obtained as:

$\mathrm{k}_{\mathrm{obs}}=8.11\left[\mathrm{H}_{2} \mathrm{O}_{2}\right]_{0}^{0.63}$

In that study, the authors neglected the hydrogen peroxide dissociation by assuming that hydrogen peroxide concentration will be constant during the reaction. However, as previously explained, the aim of advanced oxidation is to generate highly reactive hydroxyl radicals by dissociating hydrogen peroxide. That mechanism is shown previously by Equation 7 and explained in the study of Colonna et al., 1999. For that reasons, constant hydrogen peroxide concentration assumption is difficult to justify in the $\mathrm{UV} / \mathrm{H}_{2} \mathrm{O}_{2}$ process. Unlike Malik and Sanyal (2004), Behnajady et al. (2006) subdivided the $\mathrm{UV} / \mathrm{H}_{2} \mathrm{O}_{2}$ process into three parts: the reaction rate caused by $\mathrm{H}_{2} \mathrm{O}_{2}$ alone, by $\mathrm{UV}$ photolysis alone and by $\mathrm{UV} / \mathrm{H}_{2} \mathrm{O}_{2}$. The kinetic equation of dye degradation was given as follows:

$$
\begin{aligned}
& -\frac{d C_{d y e}}{d t}= \\
& k_{1} \cdot\left[\mathrm{H}_{2} \mathrm{O}_{2}\right]_{0}^{\mathrm{a}}\left[C_{d y e}\right]+\mathrm{k}_{2} \cdot \mathrm{I}_{0}^{\mathrm{b}} \cdot\left[C_{d y e}\right]+\mathrm{k}_{3} \cdot \mathrm{I}_{0}^{\mathrm{m}} \cdot\left[\mathrm{H}_{2} \mathrm{O}_{2}\right]_{0}^{\mathrm{n}}\left[C_{d y e}\right]
\end{aligned}
$$

where $\mathrm{k}_{1}, \mathrm{k}_{2}$ and $\mathrm{k}_{3}$ are the rate constants with $\mathrm{H}_{2} \mathrm{O}_{2}$ alone, UV alone and UV/ $\mathrm{H}_{2} \mathrm{O}_{2}$, respectively. $\mathrm{I}_{\mathrm{o}}$ represents the light intensity whereas $\mathrm{a}, \mathrm{b}, \mathrm{m}$ and $\mathrm{n}$ are the reaction orders.

Their results showed that the removal of dye was negligible with $\mathrm{H}_{2} \mathrm{O}_{2}$ alone $\left(\mathrm{k}_{1} \approx 0\right)$. Therefore equation 27 becomes:

$-\frac{d C_{d y e}}{d t}=\left(\mathrm{k}_{2} \cdot \mathrm{I}_{0}^{\mathrm{b}}+\mathrm{k}_{3} \cdot \mathrm{I}_{0}^{\mathrm{m}} \cdot\left[\mathrm{H}_{2} \mathrm{O}_{2}\right]_{0}^{\mathrm{n}}\right) \cdot\left[\mathrm{C}_{\text {dye }}\right]$

The effect of initial dye concentration is inserted as a multiplicative effect on that equation. To consider this effect, a regression model in Equation 24 is fitted to a relative increase in $k_{a p}$ for different initial dye concentrations where $\psi$ dye is named initial dye concentration index. In that regression model, dependent variables are the relative increase in $k_{a p}$ values with respect to $\mathrm{k}_{\mathrm{ap}}$ at $30 \mathrm{mg}$ dye $/ \mathrm{L}$. Using least square method coefficients of the linear regression model, given in Equation 29, are calculated.

$$
\psi \text { dye }=11.065 \cdot \frac{1}{[\text { Cdye }]_{0}}+0.6532
$$

In both processes, a linear regression method using $\mathrm{k}_{\mathrm{ap}}$ and $\psi$ dye values at low and high concentrations was employed to obtain reaction orders of $\mathrm{H}_{2} \mathrm{O}_{2}$ concentration and light intensity. With substituting the reaction orders for $\mathrm{H}_{2} \mathrm{O}_{2}$, light intensity and $\psi_{\text {dye }}$ in the above reaction, rate expressions given in Equation 30-31 are obtained for degradation of dye in the $\mathrm{UV} / \mathrm{H}_{2} \mathrm{O}_{2}$ process for $0 \mathrm{mg} / \mathrm{L}<\left[\mathrm{H}_{2} \mathrm{O}_{2}\right]_{0}<650 \mathrm{mg} / \mathrm{L}$, and $650 \mathrm{mg} / \mathrm{L}$ $<\left[\mathrm{H}_{2} \mathrm{O}_{2}\right]_{0}<1500 \mathrm{mg} / \mathrm{L}$ respectively. The light intensity in these equations varies from 0 to $44 \mathrm{~W} \mathrm{~m}^{-2}$ while the initial dye concentration is between 10 and $30 \mathrm{mg} / \mathrm{L}$.

$$
\begin{aligned}
& -\frac{d C_{d y e}}{d t}= \\
& \left(2 \cdot 10^{-4} \cdot \mathrm{I}_{0}^{0.75}+3 \cdot 10^{-4} \cdot \mathrm{I}_{0}^{1.38} \cdot\left[\mathrm{H}_{2} \mathrm{O}_{2}\right]_{0}^{0.49}\right) \cdot \psi \text { dye. }\left[\mathrm{C}_{\text {dye }}\right]
\end{aligned}
$$

$$
\begin{aligned}
& -\frac{d C_{d y e}}{d t}= \\
& \left(2 \cdot 10^{-4} \cdot \mathrm{I}_{0}^{0.75}+0.1 \cdot \mathrm{I}_{0}^{1.38} \cdot\left[\mathrm{H}_{2} \mathrm{O}_{2}\right]_{0}^{-0.39}\right) \cdot \psi \text { dye. }\left[\mathrm{C}_{\text {dye }}\right]
\end{aligned}
$$

Hence, in the study of Behnajady et al. (2006) a rate equation was developed that correlates the reaction rate to light intensity, initial dye and $\mathrm{H}_{2} \mathrm{O}_{2}$ concentrations. Although the rate expression was empirical, the authors clarified that it provides detailed information about the influence of operational parameters on the reaction rate. Note that the $\mathrm{H}_{2} \mathrm{O}_{2}$ reaction order was reported as 0.69 for a mixture of three azo dyes in the study of Malik and Sanyal (2004). On the other hand, it is reported as -0.39 and 0.49 in that study for high and low initial $\mathrm{H}_{2} \mathrm{O}_{2}$ concentrations, respectively. The authors attributed this difference to different chemical structures of different azo dyes. However, the results can also be attributed to the difference in the range of $\mathrm{H}_{2} \mathrm{O}_{2}$ concentrations and UV light intensity, the use of different photocatalytic reactors with different designs and different operating conditions. 
In the study of Chang et al. (2010), the effects of initial $\mathrm{H}_{2} \mathrm{O}_{2}$ and dye concentrations, $\mathrm{pH}$, and power of UV radiation on decolorization rate were predicted by a kinetic model based on the reaction network analysis shown in Figure 1.

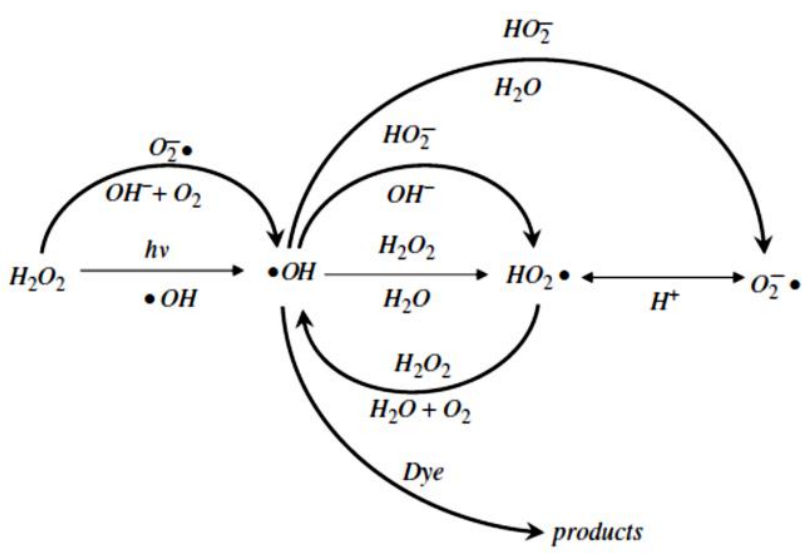

Figure 1. The reaction network for azo dye degradation using UV/ $\mathrm{H}_{2} \mathrm{O}_{2}$ as proposed by Chang et al. (2010).

The following dye decomposition rate was derived for three main pathways, assuming that the pseudo-steady state can be used for hydroxyl and hydroperoxyl free radicals:

$-r_{\text {dye }}=r_{1}+r_{2}+r_{3}$

Pathway 1:

$\mathrm{H}_{2} \mathrm{O}_{2} \underset{\mathrm{OH}-+\mathrm{O} 2}{\stackrel{\text { O2-. }}{\longrightarrow}} \cdot \mathrm{OH} \stackrel{\text { Dye }}{\longrightarrow}$ Product

Pathway 2:

$\mathrm{H}_{2} \mathrm{O}_{2} \underset{\mathrm{OH}}{\stackrel{h v}{\rightarrow}} \cdot \mathrm{OH} \stackrel{\text { Dye }}{\longrightarrow}$ Product

Pathway 3:

$\mathrm{O}_{2}^{-} \cdot \underset{\mathrm{OH}}{\stackrel{\mathrm{H+}}{\longrightarrow}} \leftrightarrow \mathrm{HO}_{2} \cdot \underset{H 2 \mathrm{O}+\mathrm{O} 2}{\stackrel{\mathrm{H2O2}}{\longrightarrow}} \cdot \mathrm{OH} \stackrel{\text { Dye }}{\longrightarrow}$ Product

$-r_{\text {dye } 0}=\frac{k_{01} k_{a} I_{0} \exp \left(-k_{H}[\mathrm{H} 2 \mathrm{O} 2]-k_{D}[\mathrm{Dye}]\right)[\mathrm{H} 2 \mathrm{O} 2][\mathrm{Dye}]\left(1+k_{b}[\mathrm{H} 2 \mathrm{O} 2]\right.}{[\mathrm{H} 2 \mathrm{O} 2]+k_{a}[\mathrm{Dye}]+k_{a} k_{b}[\text { Dye }][\mathrm{H} 2 \mathrm{O} 2]}$

In comparison to other studies that use a pseudo-firstorder kinetic model, that study specifies the individual reaction rate coefficient between the azo dye and the hydroxyl radical (Chang et al., 2010). Studies reviewed in this section indicate that the azo dye degradation process can be successfully approximated with a firstorder decay model. In the studies reviewed, different explanations for the decay rate constant are developed to come up with a better explanation for the dye degradation process. In the following section, a mathematical model for a reactor that is used for the photocatalytic dye degradation process is explained.

\section{Reactor Design Model}

Shen and Wang (2002) developed a model for photoreactor design for azo dye decomposition with
$\mathrm{UV} / \mathrm{H}_{2} \mathrm{O}_{2}$. That model can be used to predict the dye degradation within different type (geometry) of photoreactors under various operating conditions. The three-dimensional transport equation in the $\mathrm{UV} / \mathrm{H}_{2} \mathrm{O}_{2}$ system is shown as follows in cylindrical coordinates with a constant density $(\rho)$ and diffusivity $\left(D_{A B}\right)$ :

$\frac{\partial C \text { dye }}{\partial t}+\left(v_{r} \frac{\partial C \text { dye }}{\partial r}+v_{\theta} \frac{1}{r} \frac{\partial C \text { dye }}{\partial \theta}+v_{z} \frac{\partial C \text { dye }}{\partial z}\right)=$

$D_{A B} \cdot\left(\frac{1}{r} \frac{\partial}{\partial r}\left(r \frac{\partial C \text { dye }}{\partial r}\right)+\frac{1}{r^{2}} \frac{\partial^{2} C \text { dye }}{\partial \theta^{2}}+\frac{\partial^{2} C \text { dye }}{\partial z^{2}}\right)-R_{d y e}$

where $\mathrm{C}_{\text {dye }}$ is dye concentration $(\mathrm{mM}), \mathrm{D}_{\mathrm{AB}}$ the binary diffusivity of dye in water $\left(1^{2} \mathrm{~s}^{-1}\right)$, and $\mathrm{R}_{\text {dye }}$ is the rate of dye photooxidation $\left(\mathrm{M} \mathrm{s}^{-1} \mathrm{~L}^{-1}\right)$.

Equation 42 was simplified under the following assumptions (Shen and Wang 2002):

1. Accumulation variability is not considered as the system is assumed to be steady-state.

2. Because an ideal plug flow is assumed, then $v_{r}=0, v_{\theta}$ $=0$, and $v_{z}=V / \tau$ constant, where $\mathrm{V}$ is the annular reactor space volume, $\tau$ is the dye-containing solution retention time within the photoreactor, $v_{z}$ is the solution velocity in the z-direction.

3. The diffusion terms are considered to be insignificant compared to the convection terms.

4. The reaction intermediates produced during the photooxidation will not interfere with the parent dye's photodegradation.

Therefore, the Equation 42 is simplified to:

$0+v_{z} \frac{\partial C d y e}{\partial z}=-R d y e$

The design equation can be written as follows for a plugflow reactor:

$\tau=\frac{V}{v_{z}}=-\int_{\text {Cdye, in }}^{\text {Cdye }}-\frac{\text { dCdye }}{\text { Rdye }}$

The photooxidation rate $\left(R_{\text {dye }}\right)$ is a function of the UV light intensity $(I)$ and the $\mathrm{H}_{2} \mathrm{O}_{2}$ dosage:

$-\mathrm{R}_{\text {dye }}=\mathrm{k} \cdot \mathrm{I}^{\mathrm{m}} \cdot\left[\mathrm{H}_{2} \mathrm{O}_{2}\right]^{\mathrm{n}} \mathrm{C}_{\text {dye }}^{\mathrm{p}}$

where $k$ is the rate constant, $I$ is the $\mathrm{UV}$ light intensity $\left(\mathrm{Wm}^{-2}\right),\left[\mathrm{H}_{2} \mathrm{O}_{2}\right]$ the $\mathrm{H}_{2} \mathrm{O}_{2}$ dosage $\left(\mathrm{mM} \mathrm{l}^{-1}\right)$ and $m, n, p$ are the orders with respect to $I, \mathrm{H}_{2} \mathrm{O}_{2}$ dosage and $C_{\text {dye }}$ and can be experimentally determined.

UV irradiance, $I$, at any point inside the reactor is related to the surface flux, Io, in the infinite line source model. Using a one-dimensional Lambert's law the functional relationship between UV irradiance and surface flux can be given as follows:

$I=I_{0} \cdot \frac{r i}{r} e^{-E(r-r i)}$

where $E$ is the monochromatic absorbance of water. E value is determined to be $0.624 \mathrm{~cm}^{-1}$ in that work.

Equation 46 is modified with the dye and $\mathrm{H}_{2} \mathrm{O}_{2}$ in the aqueous stream as:

$I=I_{0} \cdot \frac{r i}{r} e^{-(E+E d y e C d y e+E H 2 O 2) \cdot(r-r i)}$ 
where the $\varepsilon$ dye and $\varepsilon_{\mathrm{H} 2 \mathrm{O} 2}$ are the molar absorption coefficients of the dye and $\mathrm{H}_{2} \mathrm{O}_{2}$ at $254 \mathrm{~nm} \mathrm{UV} \mathrm{light} \mathrm{and}$ were determined as 12.716 and $19 \mathrm{M}^{-1} \mathrm{~cm}^{-1}$, respectively.

The terms $\varepsilon$ dye $C_{\text {dye }}$ and $\varepsilon_{\mathrm{H} 2 \mathrm{O} 2} C_{\mathrm{H} 2 \mathrm{O} 2}$ shown in Equation 47 represent the radiation decrease caused by dye and $\mathrm{H}_{2} \mathrm{O}_{2}$ absorption. Combining Equations $43-45$ and 47 yields:

$\frac{\partial C \text { dye }}{\partial \tau}=\left(v_{z} \frac{\partial C \text { dye }}{\partial z}\right)=-R_{d y e}$

$=\mathrm{k}\left[I_{0} \cdot \frac{r i}{r} e^{-(E+E d y e C d y e+E H 2 O 2 . C H 2 O 2) \cdot(r-r i)}\right]^{\mathrm{m}} \cdot\left[\mathrm{H}_{2} \mathrm{O}_{2}\right]^{\mathrm{n}} \mathrm{C}_{\text {dye }}{ }^{\mathrm{p}}$

Integration of Eq. (48) for the whole length of the reactor gives:

$\int_{\text {Cdye, in }}^{\text {Cdye eff }} \frac{\text { dCdye }}{C_{d y e^{.}}^{p} e^{-\varepsilon d y e . C d y e . m(r-r i)}}=$

$k\left[I_{0} \cdot \frac{r i}{r} e^{-(E+E H 2 O 2 . C H 2 O 2) \cdot(r-r i)}\right]^{\mathrm{m}} \cdot\left[\mathrm{H}_{2} \mathrm{O}_{2}\right]^{\mathrm{n}} \cdot \mathrm{L} / \mathrm{v}_{\mathrm{z}}$

where $C_{\text {dye,in }}$ and $C_{\text {dye,eff }}$ are the influent and effluent concentrations of dye $(\mathrm{mM})$. The integrated value of $C_{\text {dye,eff }}(r)$ depends on radial distance, $r$, since UV light attenuates as radial distance increases.

The average residual concentration of dye, $C_{\text {dye, eff,ave, in }}$ the photoreactor effluent is calculated with the following equation.

$C_{d y e, e f f, \text { ave }}=\frac{\int_{0}^{2 \pi} \int_{r i}^{r 0} C d y e, e f f(r) d r d \theta}{\int_{0}^{2 \pi} \int_{r i}^{r 0}(r) d r d \theta}=$

$C_{d y e, e f f, a v e}\left(I_{0}, C_{d y e}, v_{z} \frac{r_{i}}{r_{0}} L, k, m, n, p\right)$

Equation 50 is the design equation for dye photodegradation in the annular reactor and in that equation $\mathrm{I}_{0}, \mathrm{C}_{\mathrm{dye}}, \mathrm{v}_{\mathrm{z}}$ are operating parameters, $\mathrm{r}_{\mathrm{i}} / \mathrm{r}_{\mathrm{o}}, \mathrm{L}$ are geometrical parameters, and $\mathrm{k}, \mathrm{m}, \mathrm{n}, \mathrm{p}$ are reaction parameters (Shen and Wang, 2002). The study by Shen and Wang (2002) is a good example of combining both empirical and mathematical models. Analysis of mathematical models starts with the unrealistic steadystate assumption in most cases and the solution of mathematical models including partial differential equations are difficult and only numerically feasible.

In the next section, studies utilized RSM to estimate azo dye degradation by $\mathrm{UV} / \mathrm{H}_{2} \mathrm{O}_{2}$ process are reviewed.

\section{Responce Surface Models}

The structures of a first and second-order response surface models are given in Equations 51 and 52 below:

$$
\begin{aligned}
& \mathrm{y}=\beta_{0}+\beta_{1} \mathrm{x}_{1}+\beta_{2} \mathrm{x}_{2}+\ldots+\beta_{\mathrm{k}} \mathrm{x}_{\mathrm{k}}+\varepsilon \\
& \mathrm{y}=\beta_{0}+\sum_{i=1}^{k} \beta_{\mathrm{i}} \mathrm{x}_{\mathrm{i}}+\sum_{i=1}^{k} \beta_{\mathrm{ii}} \mathrm{x}_{\mathrm{i}}^{2}+\sum \sum_{\mathrm{i}<j} \beta_{\mathrm{ij}} \mathrm{x}_{\mathrm{i}} \mathrm{x}_{\mathrm{j}}+\varepsilon
\end{aligned}
$$

where stands for predicted response, $\beta_{0}$ is intercept, $\beta_{i}$ first order term for factor $i, \beta_{i i}$ is the second order term for factor $i$ and, represents the interaction effect. $x_{i}$ and $x_{j}$ are factor values in the experiment (e.g., $\mathrm{pH}$, temperature).

The interaction term is a measure of how much the dependent variable, with respect to one factor, changes as the other factor increases or decreases (Palasota et al., 1992).

Response surface methodology has recently been successfully applied to different processes for achieving their optimization (Savun-Hekimoglu and Ince 2019). However, the application of RSM to a UV/ $\mathrm{H}_{2} \mathrm{O}_{2}$ process has not been widely reported. Table 2 summarizes the relevant literature on RSM studies for azo dye degradation by $\mathrm{UV} / \mathrm{H}_{2} \mathrm{O}_{2}$.

\begin{tabular}{|c|c|c|c|}
\hline Response & Variables & Optimimum conditions & References \\
\hline $\begin{array}{l}\text { Decolorization } \\
\text { Dearomatization }\end{array}$ & $\begin{array}{l}\text { initial dye concentration }\left(\mathrm{c}_{\mathrm{d} 0}\right) \\
\text { initial } \mathrm{H}_{2} \mathrm{O}_{2} \text { concentration }\left(\mathrm{c}_{\mathrm{hO}}\right) \text {, } \\
\mathrm{pH}\end{array}$ & $\begin{array}{l}\text { Decolorization: } \mathrm{c}_{\mathrm{d} 0}: 250 \mathrm{mg} \mathrm{L}^{-1} \mathrm{c}_{\mathrm{h} 0}: 30 \\
\mathrm{mM} \\
\mathrm{pH}: 7.30 \\
\text { Dearomatization: } \\
\mathrm{c}_{\mathrm{d} 0}: 250 \mathrm{mg} \mathrm{L}^{-1} \mathrm{c}_{\mathrm{h} 0}: 30 \mathrm{mM} \\
\mathrm{pH}: 6.87\end{array}$ & $\begin{array}{l}\text { Zuorro et al., } \\
2013\end{array}$ \\
\hline Decolorization & Dye $(\mathrm{mM}), \mathrm{H}_{2} \mathrm{O}_{2}(\mathrm{M}), \mathrm{pH}$ & $0.005 \mathrm{mM}$ dye, $0.042 \mathrm{M} \mathrm{H}_{2} \mathrm{O}_{2}, 6.6 \mathrm{pH}$ & $\begin{array}{l}\text { Rauf et al., } \\
2008\end{array}$ \\
\hline Decolorization & $\begin{array}{l}\text { Initial concentration of Dye- } 1 \\
(\mathrm{mg} / \mathrm{L}), \text { Dye- } 2 \\
(\mathrm{mg} / \mathrm{L}), \text { Dye- } 3(\mathrm{mg} / \mathrm{L}) \text {, initial } \\
\mathrm{H}_{2} \mathrm{O}_{2} \\
\text { concentration }(\mathrm{mg} / \mathrm{L}) \text {, reaction } \\
\text { time (min) }\end{array}$ & $\begin{array}{l}4 \mathrm{mg} / \mathrm{L} \text { dye (three dyes' initial } \\
\text { concentrations), } 48 \mathrm{mg} / \mathrm{L} \mathrm{H}_{2} \mathrm{O}_{2} \text { and } 30 \\
\text { min }\end{array}$ & $\begin{array}{l}\text { Khataee et al., } \\
2012\end{array}$ \\
\hline Decolorization & $\begin{array}{l}\text { initial dye concentration, } \mathrm{H}_{2} \mathrm{O}_{2} \\
\text { concentration, reaction time and } \\
\text { distance from UV lamp }\end{array}$ & $\begin{array}{l}20 \mathrm{mg} / \mathrm{L} \text { initial dye concentration, } 1 \mathrm{~g} / \mathrm{L} \\
\mathrm{H}_{2} \mathrm{O}_{2} \text { concentration, } 14 \text { min reaction } \\
\text { time, and } 16 \mathrm{~cm} \text { distance from the } \mathrm{UV} \\
\text { lamp. }\end{array}$ & $\begin{array}{l}\text { Khataee and } \\
\text { Habibi, } 2010\end{array}$ \\
\hline $\begin{array}{l}\text { Mineralization } \\
\text { (TOC\% decay) }\end{array}$ & $\begin{array}{l}\text { Temperature }\left({ }^{\circ} \mathrm{C}\right), \mathrm{H}_{2} \mathrm{O}_{2}(\mathrm{mM}), \\
\text { Time }(\min )\end{array}$ & $217^{\circ} \mathrm{C}, 111 \mathrm{mM}$, and $60 \mathrm{~min}$ & $\begin{array}{l}\text { Kayan and } \\
\text { Gözmen, } 2012\end{array}$ \\
\hline
\end{tabular}

Table 2. RSM studies in the literature to evaluate degradation of azo dyes by $\mathrm{UV} / \mathrm{H}_{2} \mathrm{O}_{2}$ process. 
In the studies summarized in Table 2, the RSM approach provided useful indications on the individual and interactive effects of the process variables on azo dye degradation via $\mathrm{UV} / \mathrm{H}_{2} \mathrm{O}_{2}$. Using $\mathrm{RSM}$ valid regression models were developed which provide reliable predictions of the performance of $\mathrm{UV} / \mathrm{H}_{2} \mathrm{O}_{2}$ reaction systems, using experimental data generated under the specified operating conditions (e.g. reactor, reagent and ambient conditions).

However, in most of those studies, optimum operating conditions were determined visually from 3-D response surface plots. Also, a sensitivity analysis was not conducted in those studies. In order to fill this gap in the literature, at the end of the following section, a RSM application is conducted for dye decolorization with the $\mathrm{UV} / \mathrm{H}_{2} \mathrm{O}_{2}$ process.

\section{Black-box modeling applications with the experimental data}

In this section of this paper, some of the models reviewed in the previous sections are applied to a set of data achieved through laboratory experiments. Reactive Black 5 (RB5) is selected as the model compound and the experimental set-up used in the study is presented in Figure 1. Four UV lamps (Philips 15-W low-pressure mercury), emitting monochromatic light at $253.7 \mathrm{~nm}$ were used. The distance between the surface of the solution and the UV lamps was $6 \mathrm{~cm}$. In order to determine the optimum $\mathrm{pH}$ in this system, $36 \mathrm{ppm}$ dye was exposed to UV irradiation in the presence of 400 $\mathrm{mg} / \mathrm{L} \mathrm{H}_{2} \mathrm{O}_{2}$ at $\mathrm{pH} \mathrm{3,4.5,7,9.5,} \mathrm{and} \mathrm{11.} \mathrm{The} \mathrm{effect} \mathrm{of}$ initial dye concentration on color removal was determined by exposing 18, 36, 45 and $72 \mathrm{ppm}$ dye to $\mathrm{UV} / \mathrm{H}_{2} \mathrm{O}_{2}$ oxidation at $\mathrm{pH}$ 7. The color analyses were carried out spectrophotometrically.
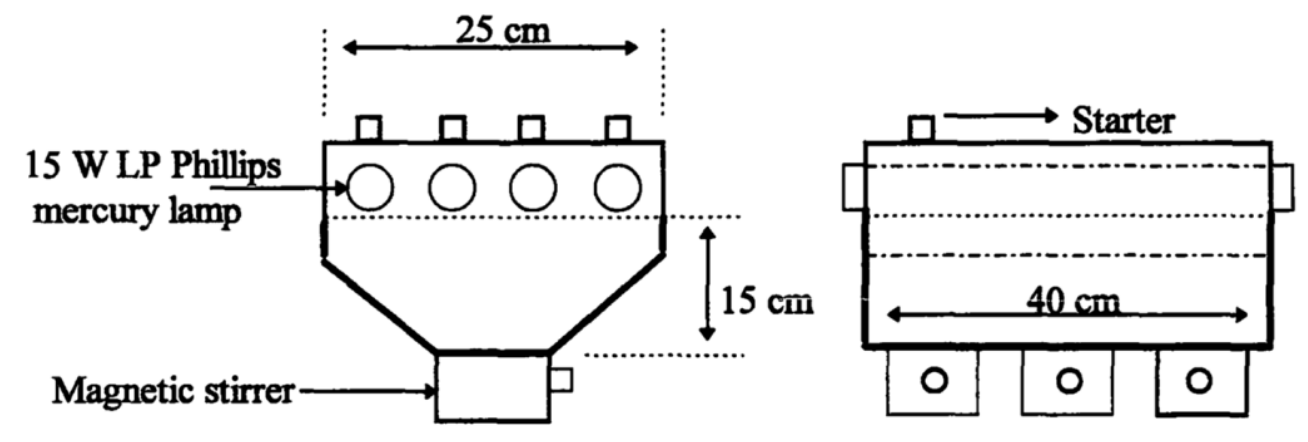

Figure 2. The schematic diagram of the photoreactor (Ince and Apikyan, 2000).

First-order decay is assumed for dye degradation in our analysis. Using Equation 2 given in the first section, reaction constant $k$ is calculated for each experiment set. These values are given in Table 3.

Table 3. Pseudo-first-order rate constants of the azo dyes photodegradation.

\begin{tabular}{lll}
\hline $\mathbf{k}\left(\mathbf{m i n}^{-1}\right)$ & $\mathbf{p H}$ & {$[\mathbf{C d y e}]_{\mathbf{0}}$} \\
\hline 0.224369 & 3 & 36 \\
0.219239 & 4.5 & 36 \\
0.192919 & 7 & 36 \\
0.240024 & 9.5 & 36 \\
\hline 0.102029 & 11 & 36 \\
0.685631 & 7 & 9 \\
0.495564 & 7 & 18 \\
$\mathbf{0 . 2 5 2 3 6 7}$ & $\mathbf{7}$ & $\mathbf{3 6}$ \\
0.104741 & 7 & 72 \\
\hline
\end{tabular}

Before developing our regression model by using RSM, first, the equations given by Behnajady et al. (2006) are applied to the observed data set in order to verify the coefficient values. Using Equations 29-30 reaction rate constant $(\mathrm{k})$ is estimated as $\mathrm{k}=0.884494 \mathrm{~min}^{-1}$. However, the observed data shows that the value of the reaction rate constant is 0.252367 . Obviously, the observed and predicted $\mathrm{k}$ values do not match with each other.
In addition to that, the equation given by Malik and Sanyal (2004) is applied to the experimentally achieved dataset as shown in Eq. (53).

$\mathrm{k}=8.11\left[\mathrm{H}_{2} \mathrm{O}_{2}\right]_{0}{ }^{0.63}=8.11(0.012)^{0.63}=0.5 \mathrm{~min}^{-1}$

It is obvious from the Equation (53) and Table 3 that the calculated result is higher than the observed $\mathrm{k}$ values. The difference between calculated and observed $\mathrm{k}$ values can be attributed to the use of different azo dyes having different chemical structures or can be attributed to different reagent doses and operating conditions. These findings indicate the need for recalculation of reaction orders and coefficient values. More accurate estimations of the coefficients and a detailed study on the comparison of the kinetic models with a wider range of experimental data are left to future research.

Although empirical models based on experimental findings exist in the literature for the $\mathrm{UV} / \mathrm{H}_{2} \mathrm{O}_{2}$ process, the effect of $\mathrm{pH}$ is still unclear and needs to be explained in detail. In this part of this study, it is aimed to fill this gap by using RSM for the data set given in Table 3. The reactions were run in the photoreactor at various preset values of $\mathrm{pH}$ and initial dye concentrations, which were chosed to be the independent variables of the model. The dependent (response) variable reflecting the efficiency of the system was selected as the first-order reaction rate constant. 
In this study, the size of the data set is nine whereas the number of experimental parameters is two $(\mathrm{pH}$ and initial dye concentration). First-order terms are included in the model as a first step. Coefficients of this model are calculated in SPSS which is a common statistics software. Summary statistics for this model are given in Table 4. Since the R-square value is found to be 0.565 , second-order terms are included in the model which is given in Equation 54.

Table 4. Summary statistics for first regression model. Model Summary

\begin{tabular}{|l|r|r|r|r|}
\hline Model & \multicolumn{1}{|c|}{$\mathrm{R}$} & $\mathrm{R}$ Square & $\begin{array}{c}\text { Adjusted } \\
\mathrm{R} \text { Square }\end{array}$ & $\begin{array}{c}\text { Std. Error of } \\
\text { the Estimate }\end{array}$ \\
\hline 1 &, $821^{\mathrm{a}}$ &, 673 &, 565 &, 12567 \\
\hline
\end{tabular}

a. Predictors: (Constant), C_0, pH

$y=b_{0}+b_{1} x_{1}+b_{2} x_{2}+b_{3} x_{1}^{2}+b_{4} x_{2}^{2}$

Montgomery (2001) states that second-order response surface models should include interaction terms as well as squares of each independent variable as shown in Equation 54. However, adding interaction terms to Equation 54 reveal that our data set is not suitable for this calculation. Therefore, RSM with a model including the interaction term is left to future research due to the requirement of additional experiments. In this paper model including only first and second-order terms without interactions is used for RSM. SPSS output including summary statistics for this model is given in Table 5. The R-square value of the model indicates that this polynomial function provides a good fit to the data set.

Table 5. Summary statistics for second regression model.

Model Summary
\begin{tabular}{|l|r|r|r|r|}
\hline Model & $R$ & R Square & $\begin{array}{l}\text { Adjusted } \\
\text { R Square }\end{array}$ & $\begin{array}{r}\text { Std. Error of } \\
\text { the Estimate }\end{array}$ \\
\hline 1 &, $989^{\mathrm{a}}$ &, 978 &, 956 &, 03997 \\
\hline
\end{tabular}
a. Predictors: (Constant), C0_2, pH, C_0, ph2
b. Dependent Variable: k

SPSS output for coefficients of the response surface model is given in Table 6. By substituting these coefficient values in Equation 54 response surface model given in Equation 55 is derived.

Table 6. Regression coefficients of the response surface model.

Coefficients

\begin{tabular}{|c|c|c|c|c|c|c|}
\hline \multirow[b]{2}{*}{ Mod } & & \multicolumn{2}{|c|}{$\begin{array}{l}\text { Unstandardized } \\
\text { Coeff icients }\end{array}$} & \multirow{2}{*}{$\begin{array}{c}\text { Standardized } \\
\text { Coefficients } \\
\text { Beta }\end{array}$} & \multirow[b]{2}{*}{$t$} & \multirow[b]{2}{*}{ Sig. } \\
\hline & & $\mathrm{B}$ & Std. Error & & & \\
\hline \multirow[t]{5}{*}{1} & (Constant) & ,777 & ,153 & & 5,066 &, 007 \\
\hline & $\mathrm{pH}$ & ,045 & ,035 & ,559 & 1,305 & ,262 \\
\hline & C_0 &,- 026 & ,003 & $-2,332$ & $-7,881$ & ,001 \\
\hline & ph2 &,- 004 & ,002 &,- 695 & $-1,614$ & ,182 \\
\hline & C0_2 & ,000 & ,000 & 1,597 & 5,372 & ,006 \\
\hline
\end{tabular}

a. Dependent Variable: $\mathrm{k}$

$$
\begin{aligned}
& \mathrm{y}=0.77+0.0451242 \mathrm{x}_{1}-0.025968 \mathrm{x}_{2}-0.003952 \mathrm{x}_{1}{ }^{2}+ \\
& 0.0002073 \mathrm{x}_{2}^{2}
\end{aligned}
$$

3-D plot for this response surface, which is given in Figure 3, is obtained from MATLAB. The contour plot for this surface is also given in Figure 4. Obviously, $\mathrm{k}$ increases steeply for low values of initial dye concentration. As one can see, there is an inverse relationship between the initial dye concentration and the reaction rate constant. Galindo and Kalt (1999) explained that an inverse relationship with an increase in the dye concentration induces a rise in the internal optical density. As the dyes react the impermeability of the solution to UV radiation increases. Therefore, the dependency of the $\mathrm{H}_{2} \mathrm{O}_{2}$-photolysis-rate to the incident intensity was reported. As a consequence, with the increasing concenrations of azo dye, the hydroxyl radicals generation of the system decreases (Muruganandham et al., 2014).

One common usage of RSM is the optimization of experiment output with respect to its parameters (Montgomery, 2001).
Since the reaction rate constant is the primary determinant for the duration of dye degradation, the maximization of $k$ value is a significant task for dye removal processes. In this study, the response surface model given above is used for calculating the optimum $\mathrm{pH}$ value which maximizes the reaction rate constant. Optimum $\mathrm{pH}$ value that maximizes reaction constant is found by taking the first derivative and having it equal to zero (Montgomery, 2001). This calculation shows that the optimum $\mathrm{pH}$ value that gives the maximum reaction constant is 5.74 . Another important issue in chemical reactions is finding the most effective parameter that can be used to control the process. For this purpose, different sensitivity analysis methods are proposed in the literature (Hamby, 1994). Among these proposed methods standardized regression coefficient (SRC) is selected for analysis of the sensitivity of rate constant to experiment parameters which are initial dye concentration $\left(\mathrm{C}_{0}\right)$ and $\mathrm{pH}$. In this method, a regression equation, which minimizes the sum of squares of residual terms, is calculated by using the ordinary least squares algorithm. The use of the regression technique allows the sensitivity ranking to be determined based on the relative magnitude of the regression coefficients (Hamby, 1994). The coefficients indicate the amount of influence the parameter has on the model as a whole. 


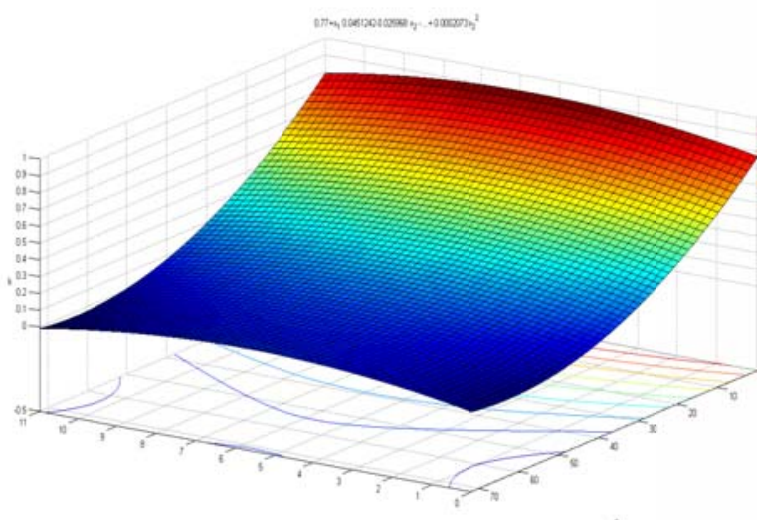

Figure 3. 3-D Plot of Response Surface for Reaction Constant $k$.

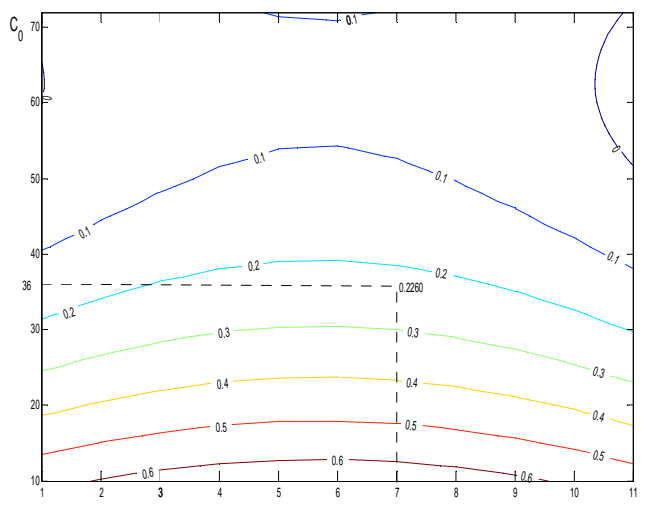

Figure 4. Contour Plot of Response Surface for Reaction Constant $k$.

Table 6. Regression coefficients of the first-order regression model.

\section{Coefficients $^{\mathrm{a}}$}

\begin{tabular}{|c|c|c|c|c|c|c|}
\hline \multirow{2}{*}{\multicolumn{2}{|c|}{ Model }} & \multicolumn{2}{|c|}{$\begin{array}{c}\text { Unstandardized } \\
\text { Coefficients }\end{array}$} & \multirow{2}{*}{$\begin{array}{c}\text { Standardized } \\
\text { Coefficients } \\
\text { Beta }\end{array}$} & \multirow[b]{2}{*}{$t$} & \multirow[b]{2}{*}{ Sig. } \\
\hline & & B & Std. Error & & & \\
\hline & (Constant) & ,665 & 166 & & 4,015 & , 007 \\
\hline & $\mathrm{pH}$ &,- 010 & 019, & -122 &,- 522 & 621 \\
\hline & C_0 &,- 009 & ,003 &,- 812 & $-3,478$ & ,013 \\
\hline
\end{tabular}

a. Dependent Variable: $\mathrm{k}$

In a standard regression model, given in Equation 55, the dependent variable $(\mathrm{y})$ is tried to be explained by $\mathrm{k}$ independent variables $\left(\mathrm{x}_{\mathrm{i}}\right)$. Standardized regression coefficients, given in Equation 56, give the importance of independent variables for the dependent one in a regression equation (Saltelli et al., 2000). In other words, the output is more sensitive to the parameters that have larger-magnitude standardized regression coefficients in the regression equation.

$\mathrm{y}=\beta_{0}+\beta_{1} \mathrm{x}_{1}+\beta_{2} \mathrm{x}_{2}+\ldots+\beta_{\mathrm{k}} \mathrm{x}_{\mathrm{k}}+\varepsilon$

$b_{j}=\frac{\beta_{j} \widehat{x_{j}}}{\widehat{\sigma}_{y}}$

In this study, experiment data, given in Table 3, is entered into SPSS and a multi-variable linear regression model is calculated of which SPSS outputs are given in Table 6 .

SRC of $\mathrm{pH}$ is found to be -0.122 whereas SRC of initial dye is calculated -0.812 . According to these results, initial dye concentration is a more significant parameter for reaction constant $k$. This conclusion can also be seen from the response surface given in Figure 3. Note that in the kinetic model of El-Dein et al. (2001) the impact of initial dye concentration was neglected. However, our findings show that the impact of initial dye concentration is not negligible. In agreement with our results, Shu et al. (1994) and Galindo and Kalt (1999) found that the decolorization rate depends on the molar ratio of $\mathrm{H}_{2} \mathrm{O}_{2}$ to the dye concentration, $\mathrm{pH}$ and chemical structure of the dye.

\section{Conclusions}

Azo dye decolorization process is studied by various researchers with empirical, semi-empirical and mathematical models. In general, experiments indicate that the azo dye degradation process can be well approximated by first-order decay model. Different studies that provide various explanations to the decay rate constant can be found in the literature. Some of the researchers consider the combined effect of UV and $\mathrm{H}_{2} \mathrm{O}_{2}$ in the decay rate constant whereas others also consider the respective effects of UV and $\mathrm{H}_{2} \mathrm{O}_{2}$ separately in an additive manner. Although numerous researchers have come up with various expressions for predicting decay rate constant $\mathrm{k}$, obviously there is no well-established model that predicts $\mathrm{k}$ value under different operating conditions. Moreover, empirical studies with response surface models, which are limited in number, are conducted to suggest the optimum operating conditions. In this study, a review of models in the literature is followed by the application of some models to a data set achieved through laboratory experiments. Calculations indicate that estimated values are slightly different than the observed decay rate constant values. This finding is attributed to different chemical structures of different azo dyes and different operating conditions.

In the next step of this study, Response Surface Methodology (RSM) is utilized in order to approximate the functional relationship between $\mathrm{k}, \mathrm{pH}$ and initial dye 
concentration. A second-order polynomial function without interaction terms is assumed for the response surface model. Coefficients of this polynomial are calculated using the least square method in SPSS. The high R-square value of this response surface model indicates that the second-order polynomial function is a proper approximation. In this paper, RSM is used to maximize the decay rate constant which plays a significant role in the decolorization process. Using this response surface model optimum $\mathrm{pH}$, maximizing the decay rate constant is calculated. The calculated optimum $\mathrm{pH}$ is in agreement with the literature.

In the last step sensitivity analysis using standardized regression coefficients (SRCs) is conducted for data set. A linear first-order regression model is assumed and SRCs are calculated using SPSS. The result of sensitivity analysis indicates that initial dye concentration is a more significant parameter for decay rate constant than $\mathrm{pH}$ value. This finding is in complete agreement with the literature reviewed above.

For further research, optimization with a response surface model including interaction terms is suggested. For that purpose, additional experiments need to be conducted with various parameter values. Also, toxicity is not analyzed or considered in any of the reviewed studies. Hence, an RSM study considering the relationship between the toxicity of the generated byproducts and the operating parameters such as $\mathrm{pH}$, $\mathrm{H}_{2} \mathrm{O}_{2}$ concentration and most importantly irradiation time seems to be necessary.

\section{Acknowledgements}

Başak Savun-Hekimoğlu is a post-doctoral researcher at Istanbul University, Institute of Marine Sciences and Management. The author is thankful to the Istanbul University Research Fund (BAP) for post-doctoral scholarship granted with an identity number MAB-201934967.

\section{References}

Aleboyeh, A., Aleboyeh, H., Moussa, Y. (2003). "Critical" effect of hydrogen peroxide in photochemical oxidative decolorization of dyes: Acid Orange 8, Acid Blue 74 and Methyl Orange. Dyes and pigments, 57(1), 67-75.

Al-Kdasi, A., Idris, A., Saed, K., Guan, C. T. (2004). Treatment of textile wastewater by advanced oxidation processes - a review. Global nest: the Int. $J, 6(3), 222-230$.

Behnajady, M. A., Modirshahla, N., Fathi, H. (2006). Kinetics of decolorization of an azo dye in UV alone and $\mathrm{UV} / \mathrm{H} 2 \mathrm{O} 2$ processes. Journal of Hazardous Materials, 136(3), 816-821.

Behnajady, M. A., Modirshahla, N., Shokri, M. (2004). Photodestruction of Acid Orange 7 (AO7) in aqueous solutions by $\mathrm{UV} / \mathrm{H} 2 \mathrm{O} 2$ : influence of operational parameters. Chemosphere, 55(1), 129-134.

Buxton, G. V., Greenstock, C. L., Helman, W. P., Ross, A. B. (1988). Critical review of rate constants for reactions of hydrated electrons, hydrogen atoms and hydroxyl radicals $\left(\cdot \mathrm{OH} / \cdot \mathrm{O}^{-}\right.$in aqueous solution. Journal of physical and chemical reference data, 17(2), 513-886.

Chafi, M., Gourich, B., Essadki, A. H., Vial, C., Fabregat, A. (2011). Comparison of electrocoagulation using iron and aluminium electrodes with chemical coagulation for the removal of a highly soluble acid dye. Desalination, 281, 285292.

Chang, M. W., Chung, C. C., Chern, J. M., Chen, T. S. (2010). Dye decomposition kinetics by UV/H2O2: Initial rate analysis by effective kinetic modelling methodology. Chemical Engineering Science, 65(1), 135-140.

Chiu, Y. H., Chang, T. F. M., Chen, C. Y., Sone, M., Hsu, Y. J. (2019). Mechanistic insights into photodegradation of organic dyes using heterostructure photocatalysts. Catalysts, 9(5), 430.

Chung, K. T. (2016). Azo dyes and human health: a review. Journal of Environmental Science and Health, Part C, 34(4), 233-261.

Colonna, G. M., Caronna, T., Marcandalli, B. (1999). Oxidative degradation of dyes by ultraviolet radiation in the presence of hydrogen peroxide. Dyes and pigments, 41(3), 211-220.

Cuerda-Correa, E. M., Alexandre-Franco, M. F., Fernández-González, C. (2020). Advanced oxidation processes for the removal of antibiotics from water. An overview. Water, 12(1), 102.

Deming, D. M. (1988). Application of response surface methodology to optimize a reduced-calorie chocolate layer cake formulation.

El-Dein, A. M., Libra, J. A., Wiesmann, U. (2003). Mechanism and kinetic model for the decolorization of the azo dye Reactive Black 5 by hydrogen peroxide and UV radiation. Chemosphere, 52(6), 1069-1077.

Fard, N. E., Fazaeli, R. (2016). A novel kinetic approach for photocatalytic degradation of azo dye with $\mathrm{CdS}$ and $\mathrm{Ag} / \mathrm{CdS}$ nanoparticles fixed on a cement bed in a continuous flow photoreactor. International Journal of Chemical Kinetics, 48(11), 691-701.

Galindo, C., Kalt, A. (1999). UV/H2O2 oxidation of azodyes in aqueous media: evidence of a structuredegradability relationship. Dyes and Pigments, 42(3), 199-207.

Gultekin, I., Ince, N. H. (2004). Degradation of reactive azo dyes by UV/H2O2: Impact of radical scavengers. Journal of Environmental Science and Health, Part A, 39(4), 1069-1081.

Hamby, D. M. (1994). A review of techniques for parameter sensitivity analysis of environmental models. Environmental monitoring and assessment, 32(2), 135-154.

Hartley, H. O. (1959). Smallest composite designs for quadratic response surfaces. Biometrics, 15(4), 611624.

Hassaan, M. A., El Nemr, A. (2017). Health and environmental impacts of dyes: mini review. American Journal of Environmental Science and Engineering, 1(3), 64-67. 
Iark, D., dos Reis Buzzo, A.J., Garcia, J.A.A., Côrrea, V.G., Helm, C.V., Corrêa, R.C.G., Peralta, R.M. (2019). Enzymatic degradation and detoxification of azo dye Congo red by a new laccase from Oudemansiella canarii. Bioresource technology, 289, 121655 .

Ince, N. H., Apikyan, I. G. (2000). Combination of activated carbon adsorption with light-enhanced chemical oxidation via hydrogen peroxide. Water Research, 34(17), 4169-4176.

Kasiri, M. B., Khataee, A. R. (2012). Removal of organic dyes by $\mathrm{UV} / \mathrm{H} 2 \mathrm{O} 2$ process: modelling and optimization. Environmental technology, 33(12), 1417-1425.

Kayan, B., Gözmen, B. (2012). Degradation of Acid Red 274 using $\mathrm{H} 2 \mathrm{O} 2$ in subcritical water: Application of response surface methodology. Journal of hazardous materials, 201, 100-106.

Khataee, A. R., Habibi, B. (2010). Photochemical oxidative decolorization of $\mathrm{CI}$ basic red 46 by $\mathrm{UV} / \mathrm{H} 2 \mathrm{O} 2$ process: Optimization using response surface methodology and kinetic modeling. Desalination and Water Treatment, 16(1-3), 243253.

Kochany, J., Bolton, J. R. (1992). Mechanism of photodegradation of aqueous organic pollutants. 2 . Measurement of the primary rate constants for reaction of hydroxyl radicals with benzene and some halobenzenes using an EPR spin-trapping method following the photolysis of hydrogen peroxide. Environmental science and technology, 26(2), 262265.

Körbahti, B. K. (2007). Response surface optimization of electrochemical treatment of textile dye wastewater. Journal of hazardous materials, 145(12), 277-286.

Kumoro, A. C., Ratnawati, R., Retnowati, D. S. (2017). Reaction and mass transfer kinetics model of hydrogen peroxide oxidation of starch under influence of ultraviolet irradiation. Periodica Polytechnica Chemical Engineering, 61(3), 236-245.

Lu, K., Zhang, X. L., Zhao, Y. L., Wu, Z. L. (2010). Removal of color from textile dyeing wastewater by foam separation. Journal of hazardous materials, 182(1-3), 928-932.

Malik, P. K., Sanyal, S. K. (2004). Kinetics of decolourisation of azo dyes in wastewater by $\mathrm{UV} / \mathrm{H} 2 \mathrm{O} 2$ process. Separation and Purification Technology, 36(3), 167-175.

Mohey El-Dein, A., Libra, J. A., Weismann, U. (2001). Kinetics of decolorization and mineralization of the azo dye Reactive Black 5 by hydrogen peroxide and UV light. Water science and technology, 44(5), 295301.

Montgomery, D. C. (2001). Design and analysis of experiments. John Wiley and Sons. Inc., New York, 1997, 200-1.
Muniyasamy, A., Sivaporul, G., Gopinath, A., Lakshmanan, R., Altaee, A., Achary, A., Chellam, P. V. (2020). Process development for the degradation of textile azo dyes (mono-, di-, poly-) by advanced oxidation process-Ozonation: Experimental and partial derivative modelling approach. Journal of Environmental Management, 265, 110397.

Muruganandham, M., Suri, R. P. S., Jafari, S., Sillanpää, M., Lee, G. J., Wu, J. J., Swaminathan, M. (2014). Recent developments in homogeneous advanced oxidation processes for water and wastewater treatment. International Journal of Photoenergy, 2014.

Neamtu, M., Siminiceanu, I., Yediler, A., Kettrup, A. (2002). Kinetics of decolorization and mineralization of reactive azo dyes in aqueous solution by the UV/H2O2 oxidation. Dyes and pigments, 53(2), 9399.

Rajchel-Mieldzioć, P., Tymkiewicz, R., Sołek, J., Secomski, W., Litniewski, J., Fita, P. (2020). Reaction kinetics of sonochemical oxidation of potassium hexacyanoferrate (II) in aqueous solutions. Ultrasonics Sonochemistry, 63, 104912.

Rauf, M. A., Marzouki, N., Körbahti, B. K. (2008). Photolytic decolorization of Rose Bengal by $\mathrm{UV} / \mathrm{H} 2 \mathrm{O} 2$ and data optimization using response surface method. Journal of Hazardous Materials, 159(2-3), 602-609.

Saltelli, A., Tarantola, S., Campolongo, F. (2000). Sensitivity anaysis as an ingredient of modeling. Statistical Science, 15(4), 377-395.

Savun-Hekimoğlu, B., Ince, N. H. (2019). Optimization of methylparaben degradation by sonocatalysis. Ultrasonics sonochemistry, 58, 104623.

Shen, Y. S., Wang, D. K. (2002). Development of photoreactor design equation for the treatment of dye wastewater by $\mathrm{UV} / \mathrm{H} 2 \mathrm{O} 2$ process. Journal of hazardous materials, 89(2-3), 267-277.

Shu, H. Y., Chang, M. C., Chang, C. C. (2009). Integration of nanosized zero-valent iron particles addition with $\mathrm{UV} / \mathrm{H} 2 \mathrm{O} 2$ process for purification of azo dye Acid Black 24 solution. Journal of hazardous materials, 167(1-3), 1178-1184.

Song, S., Fan, J., He, Z., Zhan, L., Liu, Z., Chen, J., Xu, X. (2010). Electrochemical degradation of azo dye CI Reactive Red 195 by anodic oxidation on $\mathrm{Ti} / \mathrm{SnO} 2$ $\mathrm{Sb} / \mathrm{PbO} 2$ electrodes. Electrochimica Acta, 55(11), 3606-3613.

Viswanathan, B. (2018). Photocatalytic degradation of dyes: An overview. Current Catalysis, 7(2), 99-121.

Zuorro, A., Fidaleo, M., Lavecchia, R. (2013). Response surface methodology (RSM) analysis of photodegradation of sulfonated diazo dye Reactive Green 19 by UV/H2O2 process. Journal of Environmental Management, 127, 28-35. 